\title{
Hydroelectric Power Plants and River Morphodynamic Processes
}

\author{
Marta Kiraga ${ }^{*}$ \\ 1 Department of Hydrotechnics, Technology and Management, Faculty of Civil and Environmental \\ Engineering, Institute of Civil Engineering, Warsaw University of Life Sciences WULS - SGGW, Poland \\ * Corresponding author's email: marta_kiraga@sggw.edu.pl
}

\begin{abstract}
Hydropower is one of the renewable energy sources. Hydropower plants generate electricity using the kinetic energy of flowing water. Although hydroelectric power plants are not as prominent as solar or wind farms, it should be noted that they generate the most significant amount of the power. They are also the most technically advanced projects. Power plants are built with different technical parameters of turbines, different sizes of dams or weirs and different ways of exploiting the energy of flowing water. A common feature, however, is the significant impact of hydroelectric power plants on the functioning of adjacent regions. The paper divides this impact into economic and local development, landscape, and ecological functions, emphasizing the interaction of these influences. The paper discusses the hydromorphological changes taking place in the immediate vicinity of the structure, as a consequence of channel development. The processes of aggradation and degradation of the channel are the answer to hydrodynamic equilibrium loss. These hydrodynamic processes are associated with the subsequent ecological response of the habitat. The most important of these include the dynamic equilibrium loss by the river and the subsequent morphological parameters striving to restore it according to Lane's relation, known as the most important principle in the fluvial morphology science. The impact of the hydropower plant on the fluvial environment results, first of all, from a significant environmental impact of the damming of the river itself. If the structure is correctly designed, maintained, and operated, it allows controlling the water conditions upstream and downstream with simultaneous energy production. Due to several geometric, hydraulic, and granulometric changes, and further, the resultant economic, landscape, and natural changes that significantly affect the operation of a region, these should be considered as early as the design stage and should be an integral part of any hydroelectric project.
\end{abstract}

Keywords: hydromorphology, river morphology, hydropower, energy, river, sediment, erosion

\section{INTRODUCTION}

Hydroelectric power plants are an alternative to fossil fuels, but appropriate natural conditions are necessary for their development. Hydroelectric plants are set on concrete dams or smaller weirs built on rivers to retain and dam up water. The water is stored in a reservoir and gradually released from it in the case of storage-based power plants or the natural water falls are used. In this way, the water sets in motion turbine blades that drive a generator to produce electricity. In other words, hydropower is a renewable energy source that uses the energy of water flowing from higher to lower elevations to generate electricity. As cited by many sources (Mason 2010; Kumar et al. 2011; Mishra et al. 2012; Askari et al. 2015; Tkáč 2018) and highlighted by practitioners, it is a technology that is not only proven, mature and predictable but usually competitively priced.

Hydropower has one of the highest conversion efficiencies of any energy source currently available (about 90\% efficiency, water to wire) (Kumar et al. 2011). It has a relatively high initial expenditure, but it has a long life as well as low operating and maintenance costs. Besides, hydropower plants are recognized as a technology with many advantages that popular science sources have called environmentally friendly, but the significant impact it has on the environment cannot be overlooked. However, the power plant turbine itself does not cause several ecological 
changes to the habitat in question. The greatest costs, material and environmental, are incurred in the erection of a hydraulic structure, such a great dam or smaller weir.

It should be noted that the water structure itself, on which the turbine is located, has many requirements concerning its foundation. Moreover, the topographical, geological and hydrological conditions determine the type of the hydraulic structure to a much greater extent than in land-based structures, which translates into the uniqueness of the situation and construction solutions. As the topography, geology, and hydrology are rarely the same in two different places, the possibility of the wide use of typical structures in hydraulic engineering cannot be expected. In order to adapt the power plant design to the existing conditions and electricity demand, the design solutions that vary by design type, system, head, or purpose, are used. A hydropower plant design can be adjusted to meet specific needs and sitespecific conditions.

Aiming to systematize the types of hydroelectric power plants, different divisions are introduced due to: the way of exploitation during a day, the construction of blocks and halls, the type of turbine sets, the size of power, the size of a slope, the cooperation between hydroelectric power plants, water pressure load, the way of obtaining a water fall. The major hydropower project types are: run-of-the-river, storage- (reservoir) based, pumped storage, and tidal technologies. The run-of-the-river power plants may have no reservoir upstream at all or a limited amount of storage facility (Fig. 1,2). Such power plants may use existing dams, they may replicate historic structures (small hydropower plants built in an old mills location - Fig. 3 a, b), causing the water level gradient, or the water dam is built as the first stage of the project.

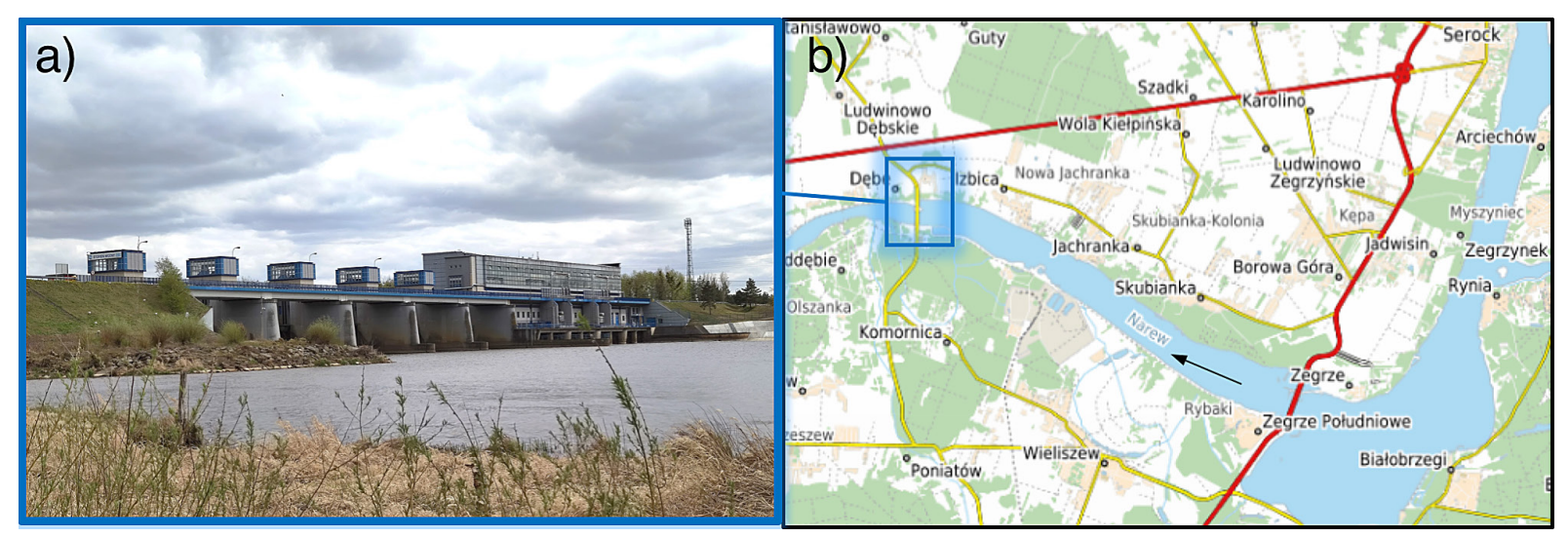

Figure 1. Dębe hydropower plant in Central Poland as an example of run-of-the-river project (Author of photography: Marta Kiraga, 2020); a) the view from downstream location; b) the valley topography

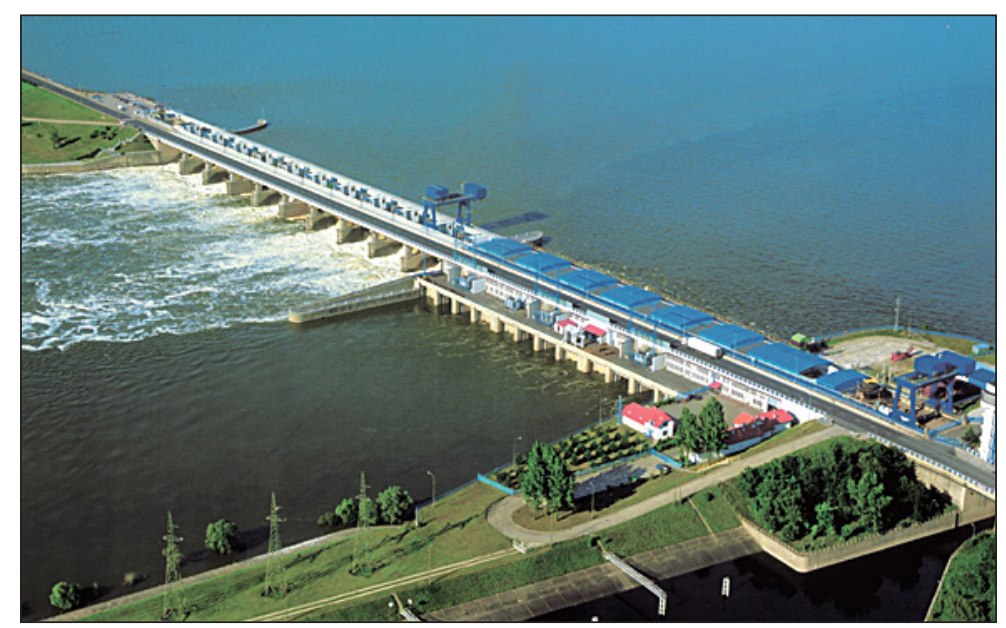

Figure 2. A photograph of the dam in Wloclawek, the largest run-of-the-river hydropower plant in Poland (Author of photography: HaskoningDHV Poland Ltd.) 
When the existing dams are used, it can be said that the greatest environmental and material cost has already been incurred in the past. In the second step, the dam is equipped with hydropower sections. Their power is limited by the natural water hydrological regime. Here, in turn, an indispensable advantage of this type of construction should be emphasized: water is a domestic resource which, contrary to fuel or natural gas, is not subject to market fluctuations. During the times of low energy demand, water flows freely through such a power plant, therefore run-ofthe-river power plants operate most efficiently if they are built where natural water surface fall could be met. Because the source of electricity is the potential energy of water, the amount of this energy is proportional to the elevation the water loses within the plant.

In the case of storage-based plants, an increase in this energy will be achieved by erecting high dams to accumulate the water. The construction of dams is accompanied by the development of a storage reservoir upstream, for drainage purposes, shipping, or for supplying water to cities, settlements, and industrial units, as well as for energy purposes. However, it should be noted that obtaining energy from flowing water, in this case, is not the only benefit of the erected structure.

Storage (reservoir) hydropower plants include a dam often of significant size and a water reservoir upstream. The cumulated water volume is retained and released later as required. The reservoir creation offers the flexibility to produce electricity on demand and eliminates the dependency on inflow fluctuations. Large reservoirs can hold inflows for months or years, but are mostly intended for seasonal storage to provide water during dry seasons. Storage hydropower plants can be run to deliver baseload power, as well as peak load by their capacity to shut down and re-start on short notice; therefore, they are recognized as more flexible than run-ofthe-river hydropower plants. Due to the ability to manage water levels, water storage reservoirs are also designed as multipurpose structures, offering added benefits such as flood control, water supply, drainage, navigation, and recreation (Killingtveit 2019).

Pumped storage hydropower plants are used to adjust the energy production to temporary demand. At times of low demand, excess energy is used to pump water into a reservoir at high elevation. At times of high demand, water is released and its potential energy is converted back into electricity.

Tidal power plants take advantage of the regularly recurring rise and fall of water levels in the ocean. Electricity in tidal power plants is generated by the ebb and flow of sea and ocean water due to the tides created by the gravitational forces of the Moon and Sun. Tides are also caused by centrifugal force due to the Earth's rotation around its center of gravity.

There is no global consensus on classifying projects by size due to varying development policies across countries (Kumar et al. 2011). Classification by size, while common and administratively simple, is to some extent arbitrary: terms such as "small" or "large" hydropower plants are not technically or scientifically rigorous indicators of impact, economics, or characteristics. The classification of hydropower plants can be based on the criteria of damming height and a)

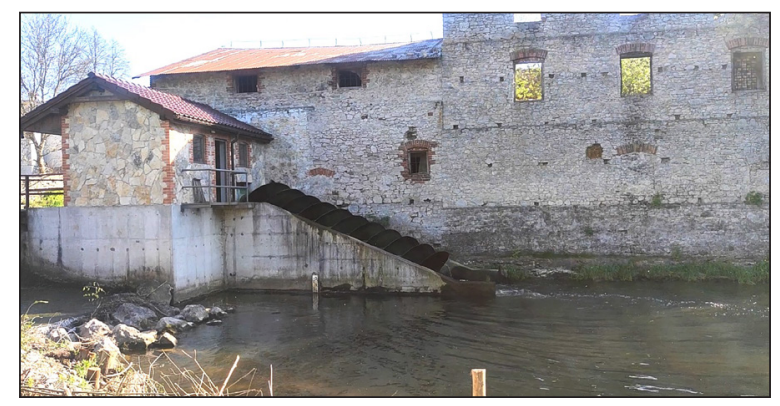

b)

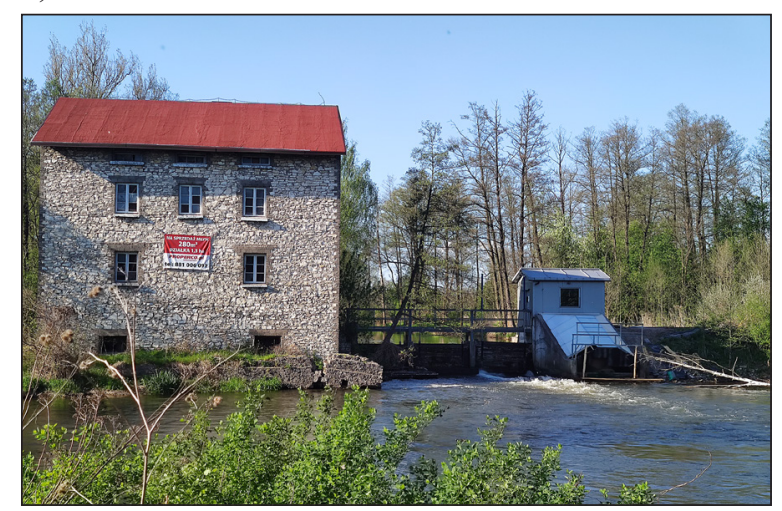

Figure 3. Small hydropower plants in old mill location a) in Wolica; b) in Morawica, Poland (Author: Marta Kiraga) 
reservoir capacity, and therefore on the type of retention induced by the erection of a water dam. For instance, the limiting value of the capacity of small retention reservoirs adopted in Poland is 5 million $\mathrm{m}^{3}$. This value was established in the Polish legislation in 1995. If the capacity of the reservoir is larger than 5 million $\mathrm{m} 3$, then the retention could be acknowledged as large. A classification of the various forms of finer reservoirs is presented in Figure 4, including all the micro and small reservoirs, which usually have a positive or minimal negative impact on the environment (Mioduszewski 2003; Szczykowska et al. 2015), while having no or little impact on the amount of power produced by an existing or planned hydroelectric plant.

Worldwide, hydropower accounts for about $16 \%$ of the electricity production (Anderson et al. 2014), which is more than in the case of any other renewable source. Recent factors for the growth of renewable energy generation, such as the European Union (EU) regulation targeting $20 \%$ of renewable energy generation by 2020 , have raised the interest in hydropower. In Poland, professional hydroelectric power plants generate about $2 \%$ of the nation's electricity production (Statistical Review of World Energy 2020). For comparison, as reported by U.S. Energy Information Administration (2020) in the United States in 2019 , the hydroelectric power produced $38 \%$ of the total renewable electricity, and $6.6 \%$ of the total U.S. electricity, meanwhile in 2018 the hydropower plants generated up to $18 \%$ of China's total electricity generation (IRENA 2018).

\section{THE HYDROPOWER PLANT IMPACT ON THE REGION}

There is a strong and evident relationship between water management and the environment, as well as between water management and development, both with opposing goals. While the need to develop and expand the hydrological infrastructure does tend to boost the economy and thus urbanization, the environmental considerations aim to steer the designer towards sustainable solutions and often to abandon the project (Koskinen et al. 2008; Rasekh et al. 2010). Hydraulic structures have a diverse range of impacts, given at least their size, and can therefore provide varying degrees of both benefits and greater or lesser risks of failure. Therefore, it is important to note that when discussing the failure of a hydraulic structure, or undesirable phenomena associated with hydraulic structure development, it does not apply only to large dams; small structures such as weirs and levees are also potential sources of disaster, affecting the life and economy of a region (Lopardo \& Seoane 2004; Maddison 2012).

Considering the rapid development of hydropower in European Union countries (Kucukali \& Baris 2009), resulting, among other things, from receiving financial and national subsidies, there is an urgent need to review the current state of knowledge on the impact of such schemes, especially given the environmental impact of hydropower plants. The erection of hydroelectric plants may contribute to a significant interference with the hydromorphological status of the river, which

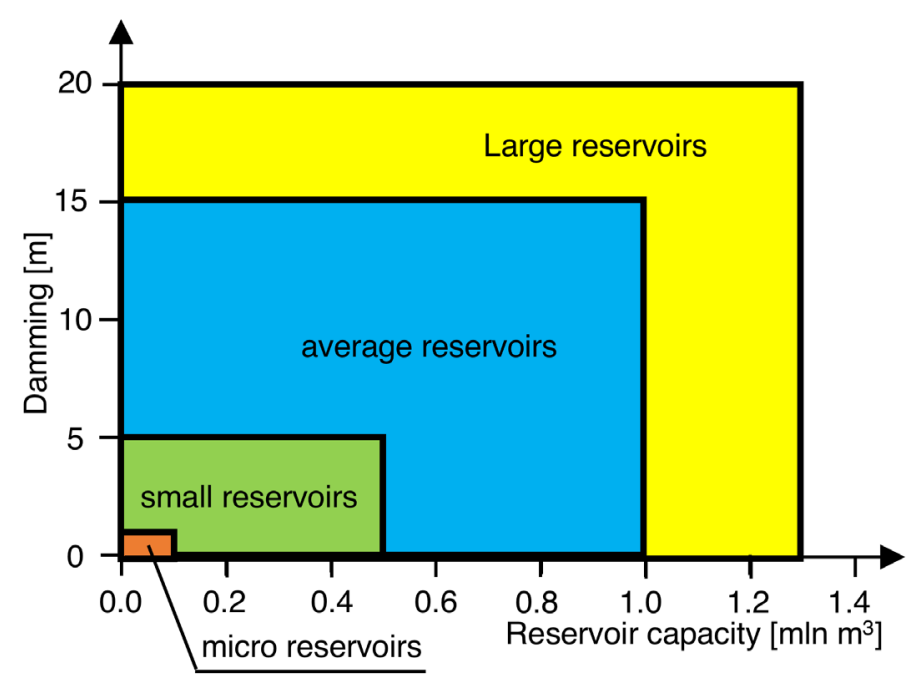

Figure 4. The classification of water reservoirs as the basis for hydropower plant classification (own elaboration Mioduszewski 2003). 
may directly translate into a failure to meet the requirements of the Water Framework Directive to achieve 'good ecological status' for all waterbodies.

The development of hydropower on the national scale is important from the point of view of increasing the share of renewable sources in electricity production, but also because of the use of damming for economic, landscape, or ecological purposes. The erection of the damming structure itself has the environmental effects which are well documented in the literature, so the impact of the hydroelectric plant on the region will come from the influence of the reservoir and the operation of the power plant itself (Fig. 5). The advantages of hydropower through the construction of a storage reservoir include improved hydrological balance and better conditions for navigation (Von Sperling 2012; Bajkowski \& Górnikowska 2013; Anderson et al. 2014; Zeleňáková et al. 2018; Li et al. 2020); however, it should be highlighted that they could negatively affect the ecosystem altering the natural hydrologic regime and the water quality, as well as the fish passage (Valero 2012).

On the other hand, there are conditions of high oxygenation in the reservoir, though both supersaturation and anoxic conditions are observed seasonally (Koszelnik \& Bartoszek 2018). The construction of hydropower plants also helps to regulate rivers and equalize flows, thus reducing

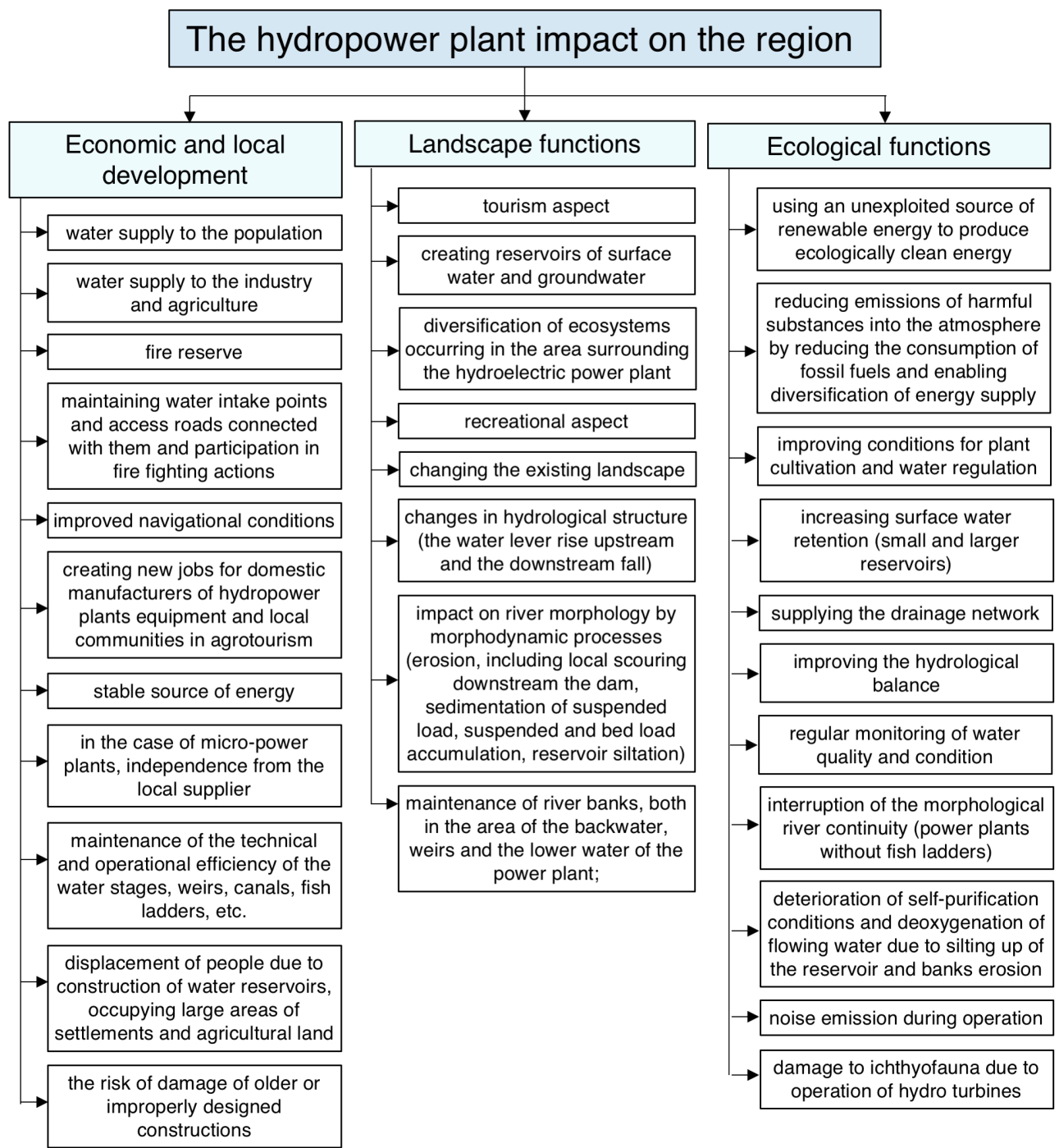

Figure 5. The hydropower plant impact on the region (own elaboration based on Bogen \& Bønsnes 2001; Radoane \& Radoane 2005; Aggidis et al. 2010; Killingtveit \& Liu 2012; Rodriguez 2012;

Valero 2012; Von Sperling 2012; Bajkowski \& Górnikowska 2013; Kline and Moretti 2013; Anderson et al. 2014; Lopes et al. 2014;; Jaskuła et al. 2015; VanCleef 2016; Çelikdemir et al. 2017; De Faria et al. 2017; Feyrer et al. 2017; Zeng et al. 2017; Koszelnik \& Bartoszek 2018; Zeleňáková et al.

2018; Fu \& Li 2019; Jachniak et al. 2019; Kumar et al. 2020; Li et al. 2020; Terêncio 2020). 
the risk of flooding (Zeng et al. 2017). Besides, hydropower plants provide jobs, which has a positive impact on the local economy (Kline and Moretti 2013; Feyrer et al. 2015; De Faria et al. 2017). The disadvantages of hydroelectric power plants are mainly the high cost of their construction (Aggidis et al. 2010; Kumar et al. 2020) and the significant interference with the environment. While the initial costs of the plant installation are significant, further operating and maintenance costs are lower, which translates into a large overall budget part participation in the initial, development stage of the project (Aggidis et al. 2010; Çelikdemir et al. 2017). The most common negative effects are silting of rivers and reservoirs (Radoane \& Radoane 2005; Jaskuła et al. 2015; Terêncio 2020), as well as increased morphodynamic processes such as erosion and accumulation, invoked by the stream velocity pattern in the region of the dam (Bogen \& Bønsnes 2001). The construction of hydroelectric power plants also involves significant landscape transformation (Rodriguez 2012; Lopes et al. 2014; Fu \& Li 2019) and displacement of people (Van Cleef 2016).

The changes in the hydrological regime will affect the whole river ecosystem. Prediction of those potential changes and managing them should be the crucial part of the hydrotechnic development of watercourses. Large dams are designed to manipulate river discharges; therefore, they impact the downstream river ecosystem by potentially affecting every part of the flow, sediment, thermal and water-quality regimes could be noticed. Dams could store lower discharges, describing the basic seasonality of the river, during the wet season. Then, they release the discharges downstream in dry seasons.

Such dam operation influences the seasonal pattern of low discharges, reversing them totally or partially, which has a significant impact on the life cycle of aquatic organisms (Power et al. 1996; Arthington 2012). For instance, aquatic plants, such as Limnobium laevigatum, Nymphaea alba, or Calla palustris need to expand their flowers above the water surface during the dry season. This process could be disrupted by the occurrence of high flows during the normally dry period in the dam area. This has further environmental consequences, namely, it prevents pollination of plants by wind and by animals. High flows, with simultaneous significant flow velocity especially in the streamline, may not allow aquatic insects to lay their eggs, which will not be able to resist the force of the flowing water (Basson 2004).

\section{HYDRODYNAMIC PROCESSES RELATED TO POWER PLANT DEVELOPMENT}

Streambed processes, understood as the changes of the riverbed under the influence of flowing waters, are considered to be one of the most dynamic phenomena transforming the Earth's surface. The fluvial environment is characterized by both erosion and sedimentation processes connected with sediment transport. Water discharge and the resulting transport of river sediment, i.e. the fluvial processes shaping the morphology of river channels, follow the feedback principle. It means that the hydraulic conditions of water discharge and the morphology of the river bed shaped by them are mutually adjusted so that the river remains in a state of dynamic equilibrium (stability) between the current water flow rate and the intensity of sediment transport (Lane 1955; Kiraga \& Miszkowska 2020).

The dynamic equilibrium conditions of a river channel were described by Lane (1955) in the form of a cause and effect relationship:

$$
Q_{s} \cdot d \sim Q_{w} \cdot J_{b}
$$

where: $Q_{s}-$ sediment transport capacity, $\left[\mathrm{m}^{3} \mathrm{~s}^{-1}\right]$;

$d$ - effective (medium) sediment grain size, $[\mathrm{m}]$;

$Q_{w}$ - water discharge (bankfull water discharge, $\left.Q_{w}=Q_{b a n k}\right),\left[\mathrm{m}^{3} \mathrm{~s}^{-1}\right]$; $J_{b}$ - stream slope, [-].

Lane's concept describes the mutual adjustment of the "restraining forces" of the sediment transport process with the "mobilizing forces" of this movement. It is often presented in the literature in the form of a pan balance, the equilibrium of which can be achieved with a practically unlimited number of variants of the load size of both pans, while appropriately locating the suspension point of the pans on the arms of the balance (Fig. 6). The sediments carried by the river will therefore either be sedimented and accumulated, leading to aggradation of the riverbed, or as a result of the significant contribution of grain moving forces, erosion processes will dominate causing the river to cut further into the valley (incision process). 


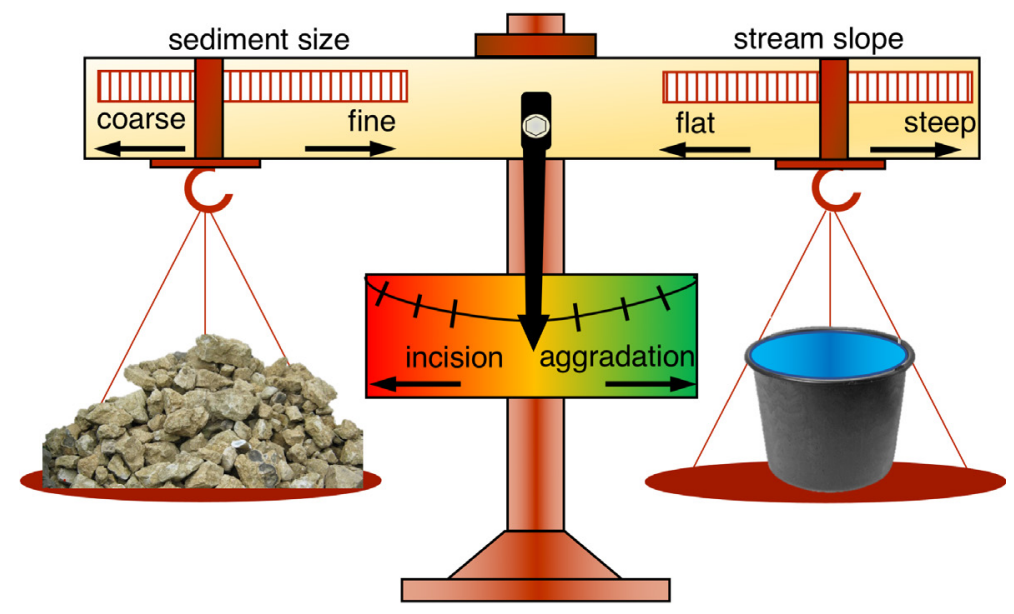

Figure 6. Lane's relation schematic (own elaboration based on Lane 1955).

The process of channel parameters adjustment caused by the changes in water and/or sediment outflow from the catchment in natural rivers usually takes place over a longer period, i.e. several decades. If, for example, a greater sediment load flows into the river from a catchment area, the bed will reach equilibrium again if the water flow rate is increased. It is also possible to reach dynamic equilibrium without increasing the water flow rate, provided that the grain size of the channel material decreases and/or the longitudinal gradient of the river increases. Lane's relation can only be used in the analyses of a qualitative nature, to predict the morphological response of a river to the changes in the hydrologic regime and/or sediment transport conditions as a result of natural and anthropogenic factors, including the introduction of hydraulic development; however, in recent years, there has been research focused on transforming it for engineering application (Kiraga \& Popek 2016; Kiraga \& Miszkowska
2020). According to Schumm (1969), in the process of recovering the lost dynamic equilibrium of the river, the individual morphological parameters of the channel are changed - their extent and directions are shown in Table 1.

The rivers in dynamic equilibrium are characterized by long-term invariability of basic channel parameters (width, depth, even bed slope). The state of dynamic equilibrium does not exclude the possibility of short-term morphological changes in the river bed resulting from the natural hydrological cycle, i.e. seasonal variability of water and sediment outflow from the catchment. The changes of the morphological parameters of the river bed in such case are usually small and oscillate around the multi-year average values.

During the channel aggradation and degradation processes the ecosystem changes, because various types of vegetation and animal species live in different types of substrates. For instance, stones appearing on banks and within the channel

Table 1. Adjustment of morphological parameters of a river channel due to changes in flow and / or supply of sediment under dynamic equilibrium conditions (own elaboration according to Schumm 1969)

\begin{tabular}{|c|c|c|c|c|c|c|c|}
\hline $\begin{array}{c}\text { Water } \\
\text { discharge }\end{array}$ & $\begin{array}{c}\text { Sediment } \\
\text { transport } \\
\text { capacity }\end{array}$ & Channel width & Water depth & $\begin{array}{c}\text { Meander } \\
\text { length }\end{array}$ & Stream slope & $\begin{array}{c}\text { River } \\
\text { sinuosity } \\
\text { coefficient }\end{array}$ & $\begin{array}{c}\text { Width-to- } \\
\text { depth ratio }\end{array}$ \\
\hline$Q_{w}$ & $Q_{s}$ & $W$ & $h$ & $L_{m}$ & $J_{b}$ & $S$ & $W / h$ \\
\hline+ & $c$ & + & + & + & - & na & na \\
\hline- & $c$ & - & - & - & + & na & na \\
\hline$c$ & + & + & - & + & + & - & na \\
\hline$c$ & - & - & + & - & - & + & na \\
\hline+ & + & + & \pm & + & \pm & - & + \\
\hline- & - & - & \pm & - & \pm & + & - \\
\hline+ & - & \pm & + & \pm & - & + & - \\
\hline- & + & \pm & - & \pm & + & - & + \\
\hline
\end{tabular}

where: "+” means increment; “-” decrement; " \pm " possible increment and decrement; "na” no impact or no recognized impact; "c" - constant 
during the process of channel degradation will provide good feeding and hiding places for animals; however, they are not a convenient site for trees. Accumulation of sandy sediments, on the other hand, will be conducive to the development of reed beds (Basson 2004).

Significantly larger morphological changes of the riverbed are most often the result of extreme flood events, after which new conditions of dynamic equilibrium are directly created. If the hydrological regime of the river is not significantly altered, then the river will regain its previous stable channel parameters after some time. In contrast, modern permanent changes in morphological parameters of river channels are mainly influenced by anthropogenic factors, such as (Clark \& Wilcock 2000; Howard et al. 2016):

- climate change;

- changes in the management of river catchments as a result of which the hydrological regime of the river is altered i.e. the characteristics of water outflow and sediment transport from the catchment change;

- river regulation;

- introduction of flood banks in river valleys;

- hydrotechnical development of rivers (retention reservoirs, damming structures, hydropower plants), as a result of which the dynamic stability of the riverbed is lost as the local conditions of water flow and transport of sediment are changed.

The issue of changes in river channel morphology is important from the point of view of hydraulic engineering, water management, flood control, and environmental protection. Increased accumulation processes have a significant impact on the water balance; they can lead to a decrease in channel capacity, also within sewer systems, a rise in bed level, which further results in a rise in the water surface within the channel and in the ground (Brandt 2000; Regueiro-Picallo et al. 2017). Uncontrolled increased water damming can have disastrous consequences during the passage of a flood wave and can lead to flooding of adjacent areas. The knowledge about the topography of the erosion and accumulation processes taking place within the channel is of paramount importance for a hydraulic engineer (Graf 1998; Kiraga 2020)

The hydrotechnical development disturbs the equilibrium state of the river channel by altering the water surface gradient and depth, and therefore the water flow velocity and sediment transport capacity. The return to equilibrium river sediment transport conditions is accomplished by gradual sediment accumulation, which affects the lifetime of the reservoir (A in Figure 7) as well as its ongoing operation (Schleiss et al. 2016; Oladosu et al. 2019). The development of a river channel usually results in a narrowing of its cross-section and changes in the flow conditions, which are particularly visible during catastrophic floods, when the basic hydrodynamic parameters of a stream are increased many times. As a result, the flow velocity is differentiated and water is dammed up upstream the construction.

The sediment-free stream leaving the damming structure, further characterized by increased kinetic energy and increased turbulence, has a high eroding capacity. After leaving the area where the hydraulic jump occurred (often in the bed region), the velocity pattern is transformed in such a way that the highest velocities occur near the bottom, i.e. in the least desirable place (B in Figure 7). Then, the velocity equalizes at some distance downstream of the hydraulic jump area ( $\mathrm{C}$ in Figure 7). These flow characteristics enable the particles of bottom material to be easily moved and detached from the bed, then absorbed by the stream and carried downstream. This results in the formation and propagation of local bed scour (D in Figure 7), bank erosion, and increased accumulation of bedload further downstream. The scour hole can threaten the stability of the structure if it develops excessively, especially during significant flow events. Therefore, in the outlet of the power plant, bank, and bottom reinforcement is used, which, in addition to preventing local scouring, reduces the energy gradient loss by decreasing the natural roughness, seals the channel and protects it against excessive filtration.

The difference in the water surface elevation upstream and downstream creates a natural inclination, and the energy of the water fall is used to generate electricity. The potential energy of the stored water is converted into kinetic energy by damming up the water with a weir or dam and flowing towards the lower level to drive a turbine. When the turbine is set in motion, it drives a generator that produces electricity, which is then fed into the power grid.

Bank erosion, which causes a change in the position of the bank line, could be recognized as a negative phenomenon by hindering the water intake for the economic or municipal purposes. 


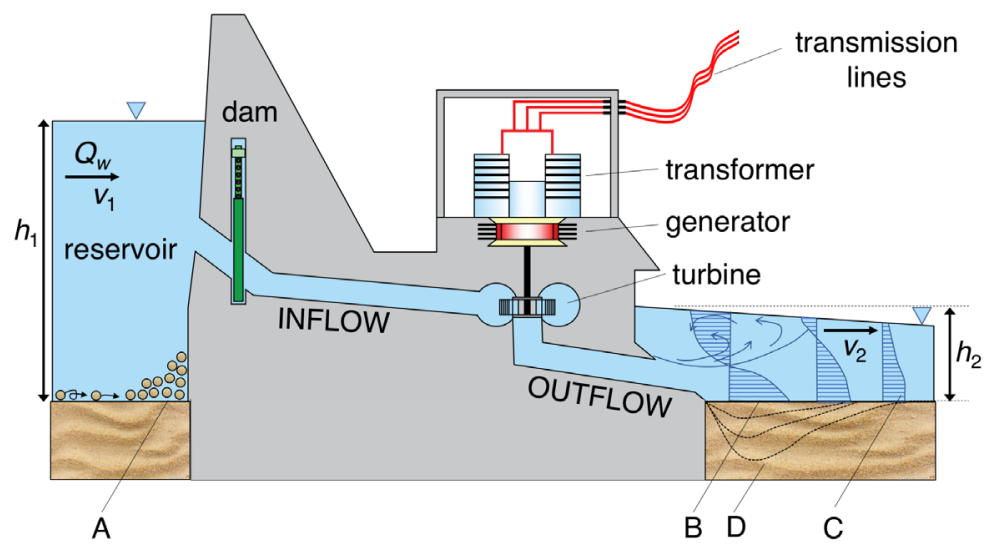

Figure 7. Diagram of hydraulic conditions accompanying the introduction of damming structures, where $Q_{w}$ - water discharge, $\left[\mathrm{m}^{3} \mathrm{~s}^{-1}\right] ; h_{1}, h_{2}-$ water depth, $[\mathrm{m}] ; v_{1}, v_{2}-$ stream velocity, $\mathrm{ms}^{-1} ; \mathrm{A}$ - accumulation region; $\mathrm{B}$ - the unfavorable velocity pattern downstream the dam; $\mathrm{C}$ - the equalized velocity pattern; $\mathrm{D}$ - the local scour deepening region.

According to Lane's relation, the following aspects of river development by the hydropower plant may be the factors increasing bank erosion: diminished sediment load leading to the activation of bed and bank material into the transport process, leading to channel incision; a decrease of sediment load delivered by the river and then stored on or near banks; constant wetting of lower bank surfaces through daily water discharge fluctuations connected with power generation, which promotes greater erodibility; channel degradation, allowing flow to be impacted low on the banks, which can remove stabilizing slopes and woody vegetation (Hupp et al. 2009). Clearing bank vegetation can prompt bank collapse, increased sediment loads in the waterway, and even environmental damages, affecting living organisms, resulting in, e.g. clogged fish gills and silting of spawning grounds, as well as reduced life of downstream reservoirs. Management of rivers and their flows should thus involve consideration of all likely responses of the river to a planned disturbance.

It should also be remembered that the transported river material carries large amounts of pollution (Wu 2007), including plant debris or much more dangerous toxic or hazardous contaminations. This has a huge impact on ecosystems not only in the lower and middle reaches of the river but also at the estuary.

As foreign substances do not degrade the river, they can be a source of ecological issues for an extensive period, regardless of whether they are resuspended for long or short time. The most dangerous foreign substances in both bedload and suspended load are metals and bioaccumulative toxins (PBTs), such as pesticides and methyl mercury (Birkett \& Lester 2005; Katagi 2006; Lino et al. 2019). Moreover, the phenomenon of additional flow contraction caused by ice phenomena carried by the river in the form of frazil ice (Fig. 8), stopping at upstream of damming structures, hindering or even preventing the power plant turbine operation, has to be mentioned. River-driven frazil ice has a crystal structure and it tends to concentrate and settle on hydraulic structure elements, especially on steel structures, posing a high hazard to proper power plant functioning (Gosink \& Osterkamp 1983). It can lead to temporary power plant operation stagnation until a permanent ice cover forms on the river or even damage to its equipment.

In the case of reservoir power plants, stored water flow velocities are low, and in engineering practice sometimes approximated to zero. Turbulence intensity and pulsation velocities are also reduced, leading to lentic environment creation (Csiki \& Rhoads 2010), which could extend for several kilometers. Such conditions exhibit lower biodiversity and cause fauna and flora diversity within its region. Various populations of benthic algae, macrophytes, macroinvertebrates, riparian vegetation and fish could be met, relative to unimpounded river reach (Mueller et al. 2011; Anderson et al. 2014).

As follows directly from Lane's relation, a decrease of the stream slope along the river channel concerning the state before damming is connected with the process of silting of the reservoir. This phenomenon is recognized as one of the main factors limiting the proper exploitation of water reservoirs (Morris \& Fan 1998; Madeyski et al. 


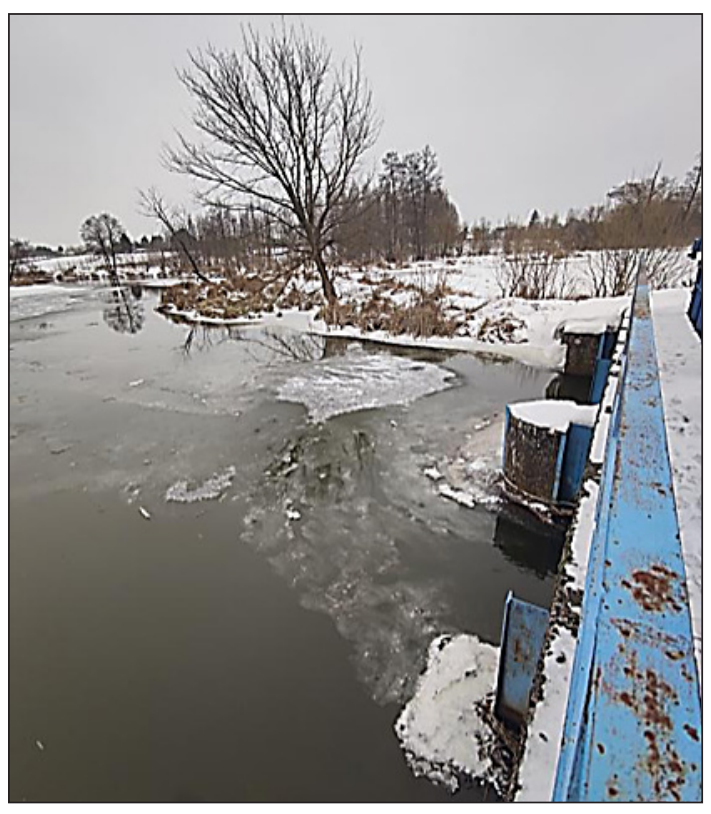

Figure 8. Ice cover retained upstream the hydraulic structure on the weir (Radomka river in Central Poland at river kilometer $44+$ 000 - winter 2021, author: Marta Kiraga).

2008). As illustrated in Figure 9, sedimentation of differentiated fractions, also including vegetable debris, takes a form with progressively finer materials being deposited as the flows approach the dam. The sediment load entering a river channel together with surface runoff depends on many factors, among which the most important are: climatic conditions, geological structure and type of soils, landform and slopes of the catchment, land use, degree of ground cover, and type of vegetation (Książek et al. 2008).

Besides trapping the sediment upstream the dam, also flood attenuation is observed, having a significant impact on discharges variability downstream. Discharges reduction will have the effect of river channel narrowing tendency. Therefore, if major tributaries do not supply the flow, then the main river tends to fill its channel with deposits and finally to narrow its cross-sections. Reservoir sedimentation occurs worldwide at an estimated rate of $0.3 \%$ year, giving an expected average reservoir life of about 300 years (Basson 2004).

Smaller reservoirs are especially prone to a rapid loss of water capacity to accumulated debris in their basins, as they are usually located in the upper parts of the catchment and act as sediment traps that intercept a large part of the debris transported by the watercourse. Small water reservoirs are silted up mainly with finegrained mineral material. The areas of high erosivity should be reforested, especially in the upper parts of the catchment, while the areas used for agricultural purposes should be transformed. In the areas where it is difficult to reduce the amount of arable land, a strip of trees or bushes should be introduced. In high parts of catchment areas, forest strips running along the contours allow reducing soil displacement, accumulating precipitation and decreasing surface runoff, thus inhibiting soil erosion. The second group of solutions limiting the amount of sediment inflow into a reservoir associated with a storage hydropower plant involves technical solutions. The places of landslides need to be secured. It is also advisable to stabilize the riverbed banks and bottom. Another approach is the construction of a bypass connecting the backwater of the reservoir with its downstream part (Scheuerlein 1999; Madeyski et al. 2008). The use of such a

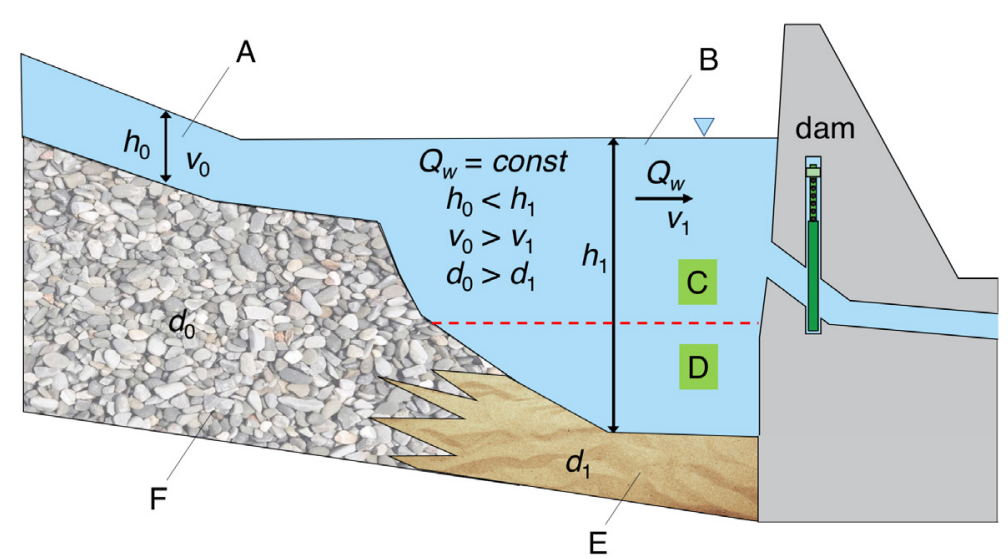

Figure 9. Typical sediment profile in the region of storage hydropower plant, where: $Q_{w}-$ water discharge, $\left[\mathrm{m}^{3} \mathrm{~s}^{-1}\right] ; h_{0}, h_{1}-$ water depth, $[\mathrm{m}] ; v_{0}, v_{1}-$ stream velocity, $\mathrm{ms}^{-1} ; d_{0}, d_{1}$ - effective (medium) sediment grain size, $[\mathrm{m}]$; A - higher velocity region; $\mathrm{B}$ - lower velocity region; $\mathrm{C}$ - the live storage area; D - the dead storage area; E - muddy lake deposits (fine); F - delta deposits (coarse). 
solution consists of three phases: interception of sediment by the intakes located at separation barriers, conducting high concentration of flow around the reservoir bypass with outflow in the downstream direction. Properly designed bypasses are acknowledged as an effective solution to the problem of excessive clastic material entering the reservoir (Madeyski et al. 2008).

A significant problem of transport of fine fractions of sediment, deposits, which pose a direct threat to the power plant operating systems, is also emphasized (Jain 2000). The water conveying elements, i.e. pipelines, adits, and storage chambers must be designed in such a manner as to avoid their accumulation sites. Hoisting mechanisms, stairs, and other elements on which deposited sediments may accumulate, must be maintained and cleaned systematically. Hydropower plant equipment, such as inlet piping, steering gear blades, vanes and turbines, is highly vulnerable to the damage from corrosion, erosion, and cavitation, which can reduce its efficiency as well as cause long and costly downtime. Repairs can involve lengthy downtime and usually need to be repeated. Fine particles entering the hydropower plant body cause erosion and deterioration of plant equipment, as well as associated infrastructure such as influent piping and spiral elements.
Long downtime, production losses, and eroded part replacement can be costly, whereas welding causes the health and safety hazards. In response to the problem of component deterioration, the key role of a high execution regime, the use of the best quality hydrotechnical concretes, and the use of durable composites for the reconstruction of worn-out power plant components is highlighted. In order to avoid excessive cavitation phenomena, the solutions based on polyurethane coatings are used to achieve a durable, flexible fluid-metal barrier, which is resistant to the implosion of air cells causing cavitation and protects equipment against it. Hydrophobic epoxy coatings are recommended as a complementary solution.

The introduction of damming structure could lead to the periodical disappearance of low discharges downstream, resulting in fish species biodiversity depletion or even demise. Mutual interconnection was described in 2004 by Basson, pointing at the significant impact of inversed hydrological regime on environmental processes taking place in the dam region (Fig. 10 $\mathrm{a}, \mathrm{b})$. The banks overgrown with vegetation are less susceptible to erosion. Roots stabilize banks, controlling the sediment delivery into the channel, and hence protecting gills, eggs, spawning, and feeding grounds. Falling trees constitute the
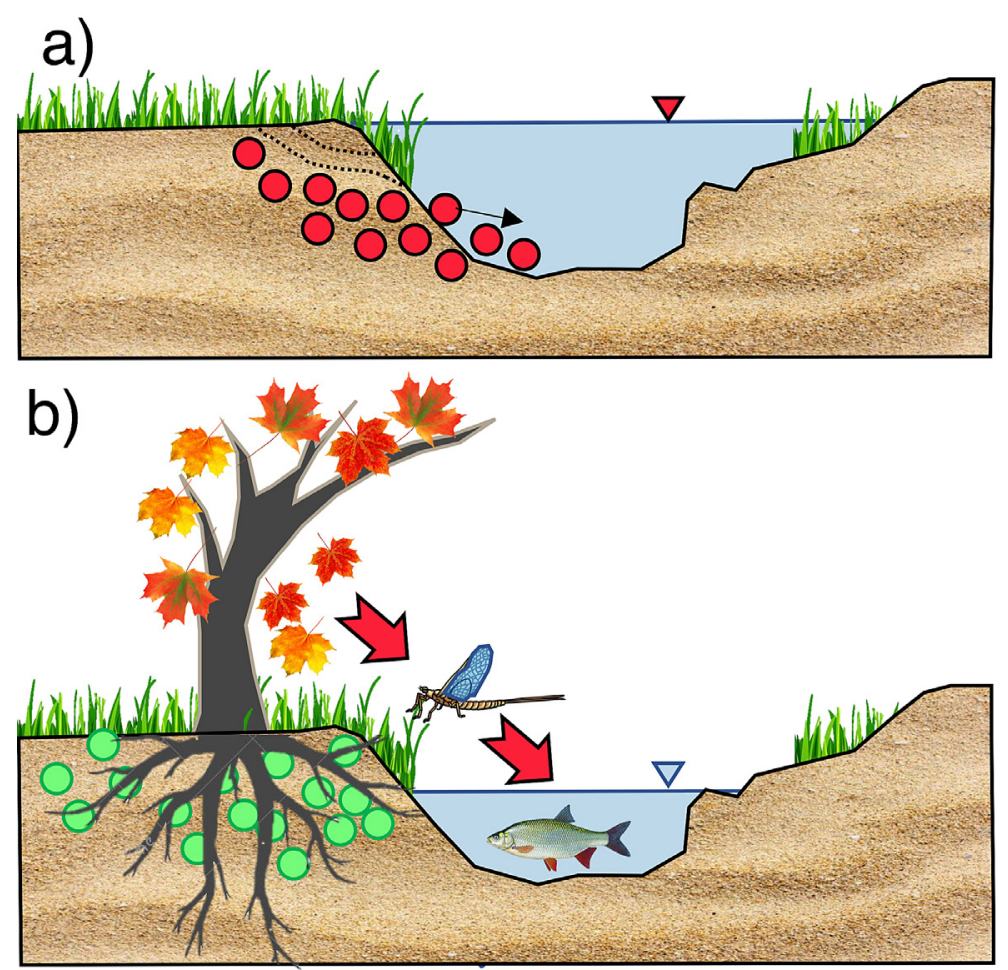

Figure 10. The impact of inversed hydrological regime on environmental processes in the dam region: a) bank-derived sediment runoff into the channel; b) bank erosion retained. 
food for insects, whose life cycle is related to the hydrological regime. Insects can be eaten later by fish. Besides, the ability to retain water in the reservoir upstream the structure and, thus, regulate the water conditions downstream, translates into the ability to control the spawning period for fish. The reduction of habitat limits biota and could increase the competition for space and food (Davey et al. 2006).

The loss of river continuum invoked by hydraulic structures hinders not only the natural downstream sediment transport but also organic matter, aquatic species, nutrients and, plant propagules, which is especially important in the case of the smaller, low-head in-river hydropower plants (Arle 2002; Csiki \& Rhoads 2010; Anderson et al. 2014). These types of power plants are often constructed in the habitats with a significant degree of habitat naturalness, which translates into highly visible and noticeable environmental effects associated with river development. By interrupting the flow, the migration of fish, those migrating between the sea and the river, or just within the river is also disrupted. Although most of the researchers demonstrate that the hydropower structure itself impedes fish migration (Lucas et al. 2009; Dugan et al. 2010; Ferguson et al. 2010 a,b; Gauld et al. 2013). Santos et al. (2006) found no significant differences in fish species, abundance, or diversity upstream or downstream of hydropower facilities. Impeded migration may be due to a physical barrier, an increased presence of unsuitable habitat as a result of altered physical conditions, or due to lethal and sublethal passage through a turbine or poorly designed mitigate solutions such as protective screens (Anderson et al. 2014) or fish ladders (Silva et al. 2012).

\section{CONCLUSIONS}

The impact of a hydropower plant induces several hydrodynamic processes that are associated with the subsequent ecological response of the habitat. The most important of these include the dynamic equilibrium loss by the river and the subsequent morphological parameters striving to restore it according to Lane's relation, known as the most important principle in the fluvial morphology science. The impact of the hydropower plant on the fluvial environment results, first of all, from a significant environmental impact of the damming of the river itself. If the structure is correctly designed, maintained, and operated, it allows controlling the water conditions upstream and downstream with simultaneous energy production. Even a small hydropower plant has an impact on the adjacent catchment area, on sediment transport pattern and further hydrodynamic phenomena occurring due to channel development.

The water structure introduction by narrowing the flow area alters the hydraulic conditions of the channel. Therefore, it contributes to the channel shaping processes acceleration and causes significant morphological changes in the riverbed, which in turn may lead to the deterioration of not only the natural features but also may adversely affect the aspect of economic use of the river. Accumulation of a part of the debris in the upper stand causes disturbance of the dynamic equilibrium between water flow and sediment transport, which, together with the increase of the stream energy caused by water damming, generates local erosion of the channel downstream the hydraulic structure.

The damming structure causes the variability of the hydrodynamic conditions along the river - average water depths and flow velocities change at successive cross-sections. Besides, downstream the damming structure, as a result of a significant increase in stream turbulence manifested by intensive pulsation of point velocities, the curvature of the streamline and the occurrence of transverse water motion occur. These processes influence the variation of depths and longitudinal velocities in the cross-section of the channel as a result of variable conditions of bedload grain motion.

Due to several geometric, hydraulic, and granulometric changes, and further, the resultant economic, landscape, and natural changes that significantly affect the operation of a region, these should be considered as early as the design stage and should be an integral part of any hydroelectric project. The main elements that impact the fluvial morphology of the habitat could be summarized as follows:

- impeding the sediment load upstream the structure, with simultaneous scouring the lower stand;

- flood attenuation with simultaneous inversion of the flow characteristic downstream the dam, translating into ecological changes, such as life cycle of the organisms; 
- bed degradation downstream the hydropower plant as an answer to sediment trapping upstream following Lane's principle.

\section{Acknowledgement}

The article was developed as a result of a research project no. 2020/04/X/ST8/01504 financed by the National Science Centre, Poland.

\section{REFERENCES}

1. Aggidis G. A., Luchinskaya E., Rothschild R., Howard D. C. 2010. The costs of small-scale hydro power production: Impact on the development of existing potential. Renewable Energy 35(12), 2632 2638. DOI: 10.1016/j.renene.2010.04.008.

2. Anderson D., Moggridge H., Warren P., Shucksmith J. 2014. The impacts of "run-of-river" hydropower on the physical and ecological condition of rivers. Water and Environment Journal 29(2), 268-276. DOI: 10.1111/wej.12101.

3. Arle J. 2002. Physical and chemical dynamics of temporary ponds on a calcareous plateau in Thuringia, Germany. Limnologica 32, 83-101. DOI: 10.1016/S0075-9511(02)80001-9.

4. Arthington A. H. 2012. Effects of Dams on Habitat and Aquatic Biodiversity. In: Environmental Flows: Saving Rivers in the Third Millennium, ed. Penrose, D., University of California Press, California, USA. DOI: 10.1525/california/9780520273696.001.0001.

5. Askari M., Mirzaei M. A., Mirhabibi M., Dehghani P. 2015. Hydroelectric energy advantages and disadvantages. American Journal of Energy Science 2(2). 17-20.

6. Bajkowski S., Górnikowska B. 2013. Hydropower production against energy from other renewable sources. Scientific Review - Engineering and Environmental Sciences 59, 77-87.

7. Basson G. 2004. Hydropower dams and fluvial morphological impacts - An African perspective. Proceedings of United Nations Symposium on Hydropower and Sustainable Development, 27-29.

8. Birkett J. W., Lester J. N. 2005. Distribution of mercury and methylmercury in the sediments of a lowland river system. Proceedings of the Royal Society A: Mathematical, Physical and Engineering Sciences 461(2057), 1335-1355. DOI: 10.1098/ rspa.2004.1408.

9. Bogen, J., Bønsnes, T. 2001. The impact of a hydroelectric power plant on the sediment load in downstream water bodies, Svartisen, northern Norway. Science of the Total Environment 266(1-3), 273-280. DOI: 10.1016/s0048-9697(01)00650-7.
10. Brandt S. A. 2000. Classification of geomorphological effects downstream of dams. CATENA 40(4), 375-401. DOI: 10.1016/s0341-8162(00)00093-X.

11. Çelikdemir S., Yıldırım B., \& Özdemir M. 2017. Cost analysis of mini hydro power plant using bacterial swarm optimization. International Journal of Energy and Smart Grid 2, 64-81. DOI: 10.23884/ IJESG.2017.2.2.05.

12. Clark J. J., Wilcock P. R. 2000. Effects of land use change on channel morphology in northeastern Puerto Rico. Geological Society of America Bulletin 112(12), 1763-1777.

13. Csiki S., Rhoads B. 2010. Hydraulic and geomorphological effects of run-of-river dams. Progress in Physical Geography 34 (6), 755- 780. DOI: 10.1177/0309133310369435.

14. Davey A., Kelly D. and Biggs B. 2006. Refuge-use strategies of stream fishes in response to extreme low flows. Journal of Fish Biology 69 (4), 10471059. DOI: $10.1111 /$ j.1095-8649.2006.01180.x.

15. De Faria F. A. M., Davis A., Severnini E., Jaramillo P. 2017. The local socio-economic impacts of large hydropower plant development in a developing country. Energy Economics 67, 533-544. DOI: 10.1016/j.eneco.2017.08.025.

16. Dugan P. J., Barlow C., Agostinho A. A., Baran E., Cada G. F. Chen D., Cowx I. G., Ferguson J. W., Healey M., Dugan P., Barlow C. 2010. Potential effects of dams on migratory fish in the Mekong river: lessons from salmon in the fraser and $\mathrm{Co}-$ lumbia rivers. Environmental Management 47(1), 141-159. DOI: 10.1007/s00267-010-9563-6

17. Ferguson J. W., Jutagate T., Mallen-Cooper M., Marmulla G., Nestler J., Petrere M., Welcomme R. L., Winemiller K. O. 2010. Fish migration, dams, and loss of ecosystem services in the Mekong basin. AMBIO 39(4), 344-348. DOI: $10.1007 /$ s13280-010-0036-1.

18. Feyrer J., Mansur E. T., Sacerdote B. 2017. Geographic dispersion of economic shocks: evidence from the fracking revolution. American Economic Review 107 (4), 1313-34. DOI: 10.1257/ aer.20151326.

19. Fu B, Li N. 2019. Tradeoff between hydropower and river Visual landscape services in mountainous areas. Sustainability 11(19), 5509. DOI: 10.3390/ su11195509

20. Gauld N., Campbell R. Lucas M. 2013. Reduced flow impacts salmonid smolt migration in a river with low-head weirs. Science of the Total Environment 458, 435-443. DOI: 10.1016/j. scitotenv.2013.04.063.

21. Gosink J., Osterkamp T. 1983. Measurements and analyses of velocity profiles and frazil ice-crystal rise velocities during periods of frazil-ice formation in rivers. Annals of Glaciology 4, 79-84. 
DOI:10.3189/S0260305500005279.

22. Graf W.H., Fluvial hydraulics, John Wiley \& Sons Ltd, Chichester, 1998.

23. Howard L., Anderson I., Underwood K., Dewoolkar M., Deschaine L., Rizzo D. 2016. Heuristic assessment of bridge scour sensitivity using differential evolution: case study for linking floodplain encroachment and bridge scour. Environmental Systems Research 5(1), 20. DOI: 10.1186/ s40068-016-0071-4.

24. Hupp C.R., Schenk E.R., Richter J.M., Peet R.K., Townsend P.A. 2009. Bank erosion along the damregulated lower Roanoke River, North Carolina, in: Management and Restoration of Fluvial Systems with Broad Historical Changes and Human Impacts, eds. James L.A., Rathburn S.L., Whittecar G.R., Geological Society of America. DOI: 10.1130/2009.2451(06).

25. IRENA (2018), Renewable Energy Statistics 2018, The International Renewable Energy Agency, Abu Dhabi.

26. Jachniak E., Jaguś A., Młyniuk A., Nycz B. 2019. The quality problems of the dammed water in the mountain forest catchment. Journal of Ecological Engineering 20(5), 165-171. DOI: $10.12911 / 22998993 / 105367$

27. Jain A.K. 2000. Silting problems in hydro power projects: Indian Scenario. In: Silting problems in hydro power plants, eds. Varma C.V.J., Naidu B.S.K., Rao A.R.G., A.A. Balkema, Rotterdam, 37-55.

28. Killingtveit Å. 2019. Hydropower. In: Managing Global Warming, ed. Letcher T., Elsevier, 265315. DOI: $10.1016 /$ b978-0-12-814104-5.00008-9.

29. Jaskuła J., Wicher-Dysarz J., Dysarz T., Sojka M. 2015. Simulation of sediment transport in the Jezioro Kowalskie reservoir located in the Glowna river. Ecological Engineering \& Environmental Technology 43, 131-138. DOI: 10.12912/23920629/58914.

30. Katagi T. 2006. Behavior of pesticides in watersediment systems. Reviews of Environmental Contamination and Toxicology 187, 133-251. DOI: 10.1007/0-387-32885-8 4. PMID: 16802581.

31. Killingtveit Å., Liu Z. 2012. Hydropower. In: IPCC Special Report on Renewable Energy Sources and Climate Change Mitigation, eds. Edenhofer O., Pichs-Madruga R., Sokona Y., Seyboth K. Matschoss P., Kadner S., Zwickel T., Eickemeier P., Hansen G., Schlömer S., von Stechow C. Cambridge University Press, Cambridge, United Kingdom and New York, NY, USA.

32. Kiraga M., Popek Z. 2016. Using a modified Lane's relation in local bed scouring studies in the laboratory channel. Water 8(1). DOI: 10.3390/w8010016.

33. Kiraga M. 2020. Local scour modelling on the basis of flume experiments. Acta Scientiarum Polonorum Architectura 18(4), 15-26. DOI: 10.22630/ ASPA.2019.18.4.41.

34. Kiraga M., Miszkowska A. 2020 Lane's relation in local scour investigations. IEEE Access 8, 146967-146975. doi: 10.1109/ ACCESS.2020.3013275.

35. Kline P., Moretti E. 2013. Local economic development, agglomeration economies, and the big push: 100 years of evidence from the Tennessee valley authority. The Quarterly Journal of Economics 129(1), 275-331. DOI: 10.1093/qje/qjt034

36. Koskinen K., Leino T., Riipinen H. 2008. Sustainable development with water hydraulics-possibilities and challenges. Proceedings of the JFPS International Symposium on Fluid Power, 11-18. DOI: 10.5739/isfp.2008.11.

37. Koszelnik P., Bartoszek L. 2018. Influence of sedimentary Fe and $\mathrm{Mn}$ on the oxygenation of overlying waters in dam reservoirs. Journal of Ecological Engineering 19(5), 180-185. DOI: 10.12911/22998993/89823.

38. Książek L., Michalik A., Śladowski T. 2008. Grainsize composition of bedload as indicator of local degradation of river channels. Acta Scientarum Polonorum Formatio Circumiectus 7(4), 3-12.

39. Kucukali S., Baris K. 2009. Assessment of small hydropower (SHP) development in Turkey: Laws, regulations and EU policy perspective. Energy Policy 37(10), 3872-3879. DOI: 10.1016/j. enpol.2009.06.023.

40. Kumar A., Schei T., Ahenkorah A., Rodriguez R., Devernay J. M., Freitas M., Hall D., Killingtveit Å, Liu Z. 2011. Hydropower. In IPCC Special Report on Renewable Energy Sources and Climate Change Mitigation, eds. Edenhofer O., Pichs-Madruga R., Sokona Y., Seyboth K., Matschoss P., Kadner S., Zwickel T., Eickemeier P., Hansen G., Schlömer S., von Stechow C. Cambridge University Press, Cambridge, United Kingdom and New York, NY, USA

41. Kumar R., Singal S. K., Dwivedi G., Shukla A. K. 2020. Development of maintenance cost correlation for high head run of river small hydro power plant. International Journal of Ambient Energy, 1-38. DOI: $10.1080 / 01430750.2020 .1804447$.

42. Lane E.W. 1955. The importance of fluvial morphology in hydraulics. Proceedings of the American Society of Civil Engineers 81(7), 1-17.

43. Li J., Moe Saw M.M., Chen S., Yu H. 2020. Shortterm optimal operation of Baluchaung II hydropower plant in Myanmar. Water 12, 504. DOI: 10.3390/ w12020504.

44. Lino A. S., Kasper D., Guida Y. S., Thomaz J. R., Malm, O. 2019. Total and methyl mercury distribution in water, sediment, plankton and fish along the Tapajós River basin in the Brazilian Amazon. 
Chemosphere 235, 690-700. DOI: 10.1016/j. chemosphere.2019.06.212.

45. Lopardo R.A., Seoane R. 2004. Floods control in Argentina: learning from the experience, in: River Flow, eds. Greco M., Caravetta A., Della Morte R. Taylor \& Francis Group, London, 1403-1409.

46. Lopes S., Vale V., Júnior J., Schiavini I., Oliveira P. 2014. Landscape changes and habitat fragmentation associated with hidroelectric plants reservoirs: insights and perspectives from a Central Brazilian case history. Bioscience Journal 30(4), 1205-1212.

47. Lucas M.C., Bubb D.H., Jang M.H., Ha K. and Masters J.E.G. 2009. Availability of and access to critical habitats in regulated rivers: effects of lowhead barriers on threatened lampreys. Freshwater Biology 54 (3), 621-634. DOI: 10.1111/j.1365-24 27.2008.02136.x.

48. Maddison B. 2012 Scour failure of bridges, Proceedings of the Institution of Civil Engineers - Forensic Engineering 165(1), 39-52. DOI: 10.1680/ feng.2012.165.1.39.

49. Madeyski M., Michalec B., Tarnawski M. 2008. Silting of small water reservoirs and quality of sediments. Infrastructure and Ecology of Rural Areas 11, 1-76.

50. Mason P. 2010. How predictable are water resources?. International Water Power and Dam Construction 62(10), 12-15.

51. Mioduszewski W. 2003. Mała retencja. Poradnik. Falenty, IMUZ [in Polish].

52. Mishra S., Singal S., Khatod D.2012. Costing of a small hydropower projects. International Journal of Engineering and Technology 4, 239-242. DOI: 10.7763/IJET.2012.V4.357.

53. Morris G. L., Fan J. 1998. Reservoir Sedimentation Manual. New York: McGraw-Hill.

54. Mueller M., Pander J. Geist J. 2011. The effects of weirs on structural stream habitat and biological communities. Journal of Applied Ecology 48 (6), 1450-1461. DOI: 10.1111/j.1365-2664.2011.020 35.x.

55. Oladosu S. O., Ojigi L. M., Aturuocha V. E., Anekwe C. O., Tanko R. 2019. An investigative study on the volume of sediment accumulation in Tagwai dam reservoir using bathymetric and geostatistical analysis techniques. SN Applied Sciences 1(5). DOI:10.1007/s42452-019-0393-8.

56. Power M.E., Dietrich W.E., Finlay J.C. 1996. Dams and downstream aquatic biodiversity: Potential food web consequences of hydrologic and geomorphic change. Environmental Management 20, 887-895. DOI: $10.1007 / \mathrm{BF} 01205969$.

57. Radoane M., Radoane N. 2005. Dams, sediment sources and reservoir silting in Romania. Geomorphology 71(1-2), 112-125. DOI: 10.1016/j. geomorph.2004.04.010.

58. Rasekh A., Afshar A., Afshar M.H. 2010. Riskcost optimization of hydraulic structures: methodology and case study. Water Resources Management 201024(11): 2833-2851. DOI: 10.1007/ s11269-010-9582-3.

59. Regueiro-Picallo M., Naves J., Anta J., Suárez J., Puertas J. 2017. Monitoring accumulation sediment characteristics in full scale sewer physical model with urban wastewater. Water Science \& Technology 76(1), 115-123. DOI: 10.2166/wst.2017.118.

60. Rodriguez J.F. 2012. Hydropower landscapes and tourism development in the Pyrenees. From natural resource to cultural heritage. Journal of Alpine Research 100-2. DOI: 10.4000/rga.1819.

61. Santos J. M., Ferreira M. T., Pinheiro A. N., Bochechas J. H. 2006. Effects of small hydropower plants on fish assemblages in medium-sized streams in central and northern Portugal. Aquatic Conservation: Marine and Freshwater Ecosystems 16(4), 373-388. DOI:10.1002/aqc.735.

62. Scheuerlein H. 1999. Reservoir sedimentation. Contribution to the Tempus Course an sediment transport - theory and practical applications, 10-15.

63. Schleiss A. J., Franca M. J., Juez C., De Cesare G. 2016. Reservoir sedimentation. Journal of Hydraulic Resources 54(6), 595-614. DOI: 10.1080/00221686.2016.1225320.

64. Schumm S.A. 1969. River metamorphosis. Journal of Hydraulics Division of American Society of Civil Engineers 95, 255-273.

65. Silva L. G. M. da, Nogueira L. B., Maia B.P., Resende L. B. de. 2012. Fish passage post-construction issues: analysis of distribution, attraction and passage efficiency metrics at the Baguari Dam fish ladder to approach the problem. Neotropical Ichthyology 10(4), 751-762. DOI: 10.1590/ S1679-62252012000400008.

66. Statistical Review of World Energy 2020 U.S. Energy Information Administration (2020) in United States (access online 1-30.03.2021).

67. Szczykowska J., Siemieniuk A., Wiater J. 2015. Diversity of the TSI Indicators in the middle-forest small retention reservoir. Journal of Ecological Engineering 16(5), 54-61. DOI: 10.12911/22998993/60454.

68. Terêncio D.P.S., Cortes R.M.V., Pacheco F.A.L., Moura J.P., Fernandes L.F.S. 2020. A method for estimating the risk of dam reservoir silting in fireprone watersheds: A study in Douro river, Portugal. Water 12, 2959. DOI: 10.3390/w12112959.

69. Tkáč S. 2018. Hydro power plants, an overview of the current types and technology. Selected Scientific Papers - Journal of Civil Engineering 13, 115-126. DOI: $10.1515 /$ sspjce-2018-0011.

70. VanCleef A. 2016. Hydropower development and 
involuntary displacement: toward a global solution. Indiana Journal of Global Legal Studies 23(1), 349-376.

71. Valero E. 2012. Characterization of the water quality status on a stretch of river Lérez around a small hydroelectric power station. Water 4, 815-834. DOI: $10.3390 / \mathrm{w} 4040815$.

72. Von Sperling E. 2012. Hydropower in Brazil: overview of positive and negative environmental aspects. Energy Procedia 18, 110-118. DOI: 10.1016/j.egypro.2012.05.023.

73. Wu W. 2007. Computational river dynamics. Taylor
\& Francis, London.

74. Zeng X. T., Zhang S. J., Feng,J., Huang G. H., Li Y. P., Zhang P., Chen J.P., Li K. L. 2017. A multireservoir based water-hydroenergy management model for identifying the risk horizon of regional resources-energy policy under uncertainties. Energy Conversion and Management 143, 66-84. DOI: 10.1016/j.enconman.2017.02.020.

75. Zeleňáková M., Fijko R., Diaconu D., Remeňáková I. 2018. Environmental impact of small hydro power plant-a case study. Environments 5, 12. DOI: 10.3390/environments5010012. 